\title{
Analysis of the influence of physical activity on body composition in women and men using bioelectrical impedance
}

\section{Analiza wpływu aktywności fizycznej na skład ciała u kobiet i mężczyzn $z$ wykorzystaniem impedancji bioelektrycznej}

\author{
Zbigniew Śliwiński, Jakub Jedlikowski, Kamil Markowski \\ Collegium Medicum, Institute of Health Sciences, Kielce, Poland
}

Medical Studies/Studia Medyczne 2021; 37 (1): 42-48

DOI: https://doi.org/10.5114/ms.2021.105000

Key words: body composition analysis, physical activity, bioelectrical impedance, physiotherapy.

Słowa kluczowe: analiza składu ciała, aktywność fizyczna, impedancja bioelektryczna, fizjoterapia.

\begin{abstract}
Introduction: The development of medicine has allowed researchers to determine in detail the composition of the body, so that they can not only treat with great effectiveness, but also prevent, the development of modern civilization diseases. Measuring body fat and fat-free mass to determining the amount of water and minerals is a technique used in the daily work of doctors, dieticians, and personal trainers. Thanks to this knowledge they can establish diets, a preferred lifestyle, and physical effort levels. The most frequently used methods are anthropometric methods, hydrodensitometry, or bioelectric impedance analysis.

Aim of the research: To analyse the influence of physical activity on body composition in both women and men using bioelectric impedance.

Material and methods: The survey was conducted twice at a monthly interval, from 10.2019 to 02.2020 . The participants were the same people, regularly attending the " 36 Minutes Kielce" gym. The analysis of body composition was performed using the InBody 170-MEDFitness device. This analyser uses the electric impedance method. The results were obtained using a diagnostic survey recording the following: height, gender, age, body weight (kg), total body water content (l), adipose tissue mass $(\mathrm{kg}, \%)$, muscle mass $(\mathrm{kg})$, protein content $(\mathrm{kg})$, mineral content $(\mathrm{kg})$, fat-free body mass $(\mathrm{kg})$, body mass index (BMI), visceral fat area, the basal metabolic rate (BMR), waist-hip ratio (WHR), segmental fat-free body mass (kg, \%), segmental fat body mass $(\mathrm{kg}, \%)$, muscle-fat control $(\mathrm{kg})$, body composition history, the impedance of each segment and frequency, the Fitness scale, and obesity analysis.

Results: The following changes were observed in the study group: average body weight decreased by $0.7 \mathrm{~kg}$ and skeletal muscle mass increased by $0.2 \mathrm{~kg}$. The average adipose tissue mass was reduced by $1.1 \mathrm{~kg}$, and consequently the water content increased by 0.21 and the fat-free mass level increased by $0.3 \mathrm{~kg}$. The WHR score decreased by 0.003 points and the visceral fat area decreased by 0.7 , hence the average value of the basal metabolic rate increased from $1436.1 \mathrm{kcal}$ to $1442.6 \mathrm{kcal}$. Normal BMI was achieved by $36.67 \%$ of the participants.

Conclusions: The muscle mass gain is related to the total body mass gain, and our own research has shown a statistically significant relationship between these parameters. The reduction of body fat as a result of physical training reduces the overall body weight, and the difference between the amount of fat and the overall body weight is statistically significant. Height and weight have an impact on the body's caloric requirements. Analysis of the value of the basic metabolic index confirms that the higher the weight and height, the greater the daily caloric demand. Physical activity affects changes in body composition, and the recorded values of body weight reduction, amount of fat, BMI, visceral fat level and skeletal muscle mass increase, and water and protein content are statistically significant.
\end{abstract}

\section{Streszczenie}

Wprowadzenie: Rozwój medycyny umożliwia badaczom szczegółowe określenie składu ciała, dzięki czemu mogą oni nie tylko leczyć z duża skutecznościa, lecz także zapobiegać rozwinięciu się współczesnych chorób cywilizacyinych. Pomiar tkanki tłuszczowej i masy beztłuszczowej, a także określenie ilości wody i minerałów są wykorzystywane w codziennej pracy lekarzy, dietetyków, trenerów personalnych. Dzięki tej wiedzy ustalaja oni diety, preferowany tryb życia i wysiłek fizyczny. Najczęściej stosowanymi metodami są: metody antropometryczne, hydrodensytometria oraz analiza impedancji bioelektrycznej.

Cel pracy: Analiza wpływu aktywności fizycznej na skład ciała u kobiet i mężczyzn przy wykorzystaniu impedancji bioelektrycznej. 
Materiał i metody: Badanie przeprowadzono dwukrotnie w miesięcznym odstępie czasowym, od października 2019 do lutego 2020 r. Uczestnikami byłe te same osoby, uczęszczające regularnie na zajęcia w siłowni „36 Minut Kielce”. Analizę składu ciała wykonywano na urządzeniu InBody 170-MEDFitness. Analizator ten wykorzystuje metodę impedancji elektrycznej. Do uzyskania wyników posłużył sondaż diagnostyczny badający: wzrost, płeć, wiek, masę ciała (kg), całkowitą zawartość wody w organizmie (l), masę tkanki tłuszczowej (kg, \%), masę tkanki mięśniowej (kg), zawartość białka (kg), zawartość substancji mineralnych $(\mathrm{kg})$, beztłuszczową masę ciała $(\mathrm{kg})$, wskaźnik masy ciała (BMI), poziom wisceralnej tkanki tłuszczowej, podstawową przemianę materii (BMR), wskaźnik talia-biodra (WHR), segmentalną beztłuszczową masę ciała (kg, \%), segmentalną tłuszczową masę ciała (kg, \%), kontrolę mięśniowo-tłuszczową (kg), historię składu ciała, impedancję każdego segmentu i częstotliwości, skalę fitness i analizę otyłości.

Wyniki: W grupie poddanej badaniu zaobserwowano następujące zmiany: średnia masa ciała zmniejszyła się o 0,7 kg, a masa mięśni szkieletowych zwiększyła się o 0,2 kg. Średnia masa tkanki tłuszczowej została zredukowana o 1,1, kg, natomiast zawartość wody wzrosła o 0,2 1, a poziom masy beztłuszczowej zwiększył się o 0,3 kg. Wynik WHR zmniejszył się o 0,003 pkt, a poziom tłuszczu wisceralnego zmniejszył się o 0,7, dlatego też wzrosła średnia wartość podstawowej przemiany materii z 1436,1 kcal do 1442,6 kcal. Prawidłowy wskaźnik BMI osiągnęło 36,67\% badanych.

Wnioski: Przyrost masy mięśni jest powiązany z przyrostem ogólnej masy ciała, a badania własne wykazały statystycznie istotny związek pomiędzy tymi parametrami. Zmniejszenie ilości tkanki tłuszczowej w organizmie w wyniku treningu fizycznego redukuje ogólną masę ciała, a różnica pomiędzy ilością tej tkanki a ogólną masą ciała w przeprowadzonych badaniach jest statystycznie istotna. Wysokość oraz masa ciała mają wpływ na zapotrzebowanie kaloryczne organizmu. Analiza wartości wskaźnika podstawowej przemiany materii potwierdza, że im większa masa oraz wysokość, tym dzienne zapotrzebowanie kaloryczne jest większe. Aktywność fizyczna wpływa na zmiany składu ciała, a zarejestrowane wartości zmniejszenia masy ciała, ilości tkanki tłuszczowej, BMI, poziomu tłuszczu wisceralnego oraz zwiększenia masy mięśni szkieletowych, zawartości wody i białka są statystycznie istotne.

\section{Introduction}

Observing the modern person, it would seem that people's awareness of the benefits of regular physical activity is increasing. Data published by the World Health Organization, which clearly proved that insufficient physical activity is the fourth most frequent risk factor responsible for untimely deaths in the world, had an unmistakeable impact on this phenomenon [1].

The human body is made for motion, that is why we feel the need for regular physical activity. People who meet that need have a rich packet of data on their health, called the body composition analysis. Body composition analysis is described as the most important modern diagnostic method, making it possible to diagnose diseases such as type 2 diabetes, hypertension, ischaemic heart disease, malignant tumours, and hyperlipaemia [2-5].

Science divides the methods of assessing the composition of a human body into laboratory ones and population ones. Hydrodensitometry, evaluation of total $40 \mathrm{~K}$ potassium isotope content, dual-energy $\mathrm{X}$-ray absorptiometry, analysis of neuronal activity, as well as the electrical conductivity method, analysis of neuronal activity, computed tomography, bioelectrical impedance analysis, magnetic resonance imaging, and the isotope dilution method are among the laboratory methods. Whereas skinfold measurements, anthropometry, and near infrared interactance are among of the population tests. The most important differences between the mentioned methods are availability, research value, accuracy, repeatability of measurement, and financial expenditure [6, 7].

Bioelectrical impedance analysis (BIA) is a noninvasive method that is of use in many domains. It determines the levels of muscle, fat, and mineral tissues, as well as the amount of water. The method is widely used in research concerned with eating disorders, in sports medicine, and in risk assessment of cardiovascular diseases and metabolic disorders. Its great advantages are the repeatability of measurement, the high percentage of accuracy, and results that are easy to obtain and interpret. The devices used for the tests are portable, relatively inexpensive, and easy to use [6-10].

\section{Aim of the research}

The objective of the study was to analyse the body composition in physically active people and evaluate its change after a training programme has been completed.

\section{Material and methods}

The study was conducted on a group of 90 people, out of which $88 \%$ were women and $12 \%$ were men. The average age of the participants was 44.76 years; the oldest was 50 years old and the youngest was 40 . The group of participants was made up of 79 women and 11 men. The women amounted to $87.78 \%$ of all the participants, whereas the men comprised $12.22 \%$. Amongst all the participants, the majority were overweight, and they accounted for $42 \%$, people with a normal body mass index (BMI) came second at $37 \%$, and the next group accounted for $17 \%$ and was formed by participants with class 1 obesity. The most numerous group was formed by people in the 44-47 age range, of whom there were $37(41.11 \%)$, there were marginally fewer participants in the 40-43 range, at $34(37.78 \%)$ people, and the $48-50$ range was the least numerous, with $19(21.11 \%)$ participants. These people were members of the " 36 Minutes Kielce" gym in the Świętokrzyskie voivodeship, who performed physical 
activity consisting of Milon strength and endurance training. In order to obtain results, tests were conducted twice within the period 10.02.2019 to 02.2020, and both measurements were done in identical atmospheric conditions, with the same people, and exactly 1 month apart. The participants gave written consent to being tested prior to the tests. Body composition analysis was done using an InBody 170 device. This analyser uses BIA, i.e. electrical impedance, also referred to as electrical bioimpedance. It is a method for the assessment of body composition, which is simple, non-invasive, and reliable. A test using this method is based on measuring impedance, meaning electrical resistance. Results are available instantly after a test, and the margin of error is a mere $1 \%$. This method is most often used in sports medicine, in research on eating disorders, as well as to predict the risk in cardiovascular and metabolic diseases. A major advantage of the InBody 170 device is that one has the possibility to input personal data such as gender, age, and height, which allows it to quickly make high-precision measurements based on numerous scales and algorithms. All data are analysed and transformed using dedicated computer software, MEDFitness 170, integrated with the InBody 170 scales.

The following parameters were measured in this study: body weight $(\mathrm{kg})$, height $(\mathrm{cm})$, total water content in the body (l), adipose tissue mass $(\mathrm{kg})$, adipose tissue mass (\%), muscle tissue mass $(\mathrm{kg})$, protein content $(\mathrm{kg})$, mineral content $(\mathrm{kg})$, fat-free body mass (kg), body mass index (BMI), visceral fat area, basal metabolic rate (BMR), waist-hip ratio (WHR), segmental fat-free body mass ( $\mathrm{kg}, \%)$, segmental adipose body mass $(\mathrm{kg}, \%)$, muscle and fat control (kg), body composition history, impedance of each segment and frequency, the Fitness scale, and obesity analysis [11].

The tests were carried out on the grounds of the "36 Minutes Kielce" gym. The room had proper conditions in it, i.e. around $22^{\circ} \mathrm{C}$. Before performing a test, each person had their height measured. Next, basic information about the participant was input into the InBody 170 analyser: gender, age, and height, and the weight of the clothing was subtracted. The name, surname, and date of birth were filled in immediately after the test, in the software that works with the analyser - MEDFitness 170. The patient was asked to correctly place their bare feet on a previously disinfected platform. The next step was to wait a few moments in order for the analyser to measure the body weight. Next, the participant took hold of the handles, with elbows in an intermediate position, and lower limbs straight at the knees. Upper limbs were placed so that they did not touch the torso. The participant stood still for a few seconds, whilst the device measured the body composition using the BIA method. A beep signalised the end of the test, and at that point the participant put the handles down onto their place, after which they could step off the platform. The test was complete. The test was performed twice between 10.2019 and 02.2020. The second test was performed on the same people and under the same conditions, after a month had passed from the initial test.

\section{Statistical analysis}

The obtained results underwent statistical analysis using Microsoft Office Excel 2013 software. The values of the parameters in the descriptive statistics were presented as minimum and maximum values, means, and medians. In order to verify the research questions, analysis of variance (ANOVA) and Pearson's correlation coefficient $(r)$ were used.

\section{Results}

Table 1 presents the statistical characteristics of the components under study and a comparison of the individual measurements: height, weight, skeletal muscle mass (SMM), adipose tissue (FAT), total body water (TBW), fat-free mass, body mass index (BMI), percentage of body fat (PBF), waist-hip ratio (WHR), visceral fat area (VFA), basal metabolic rate (BMR), minerals, protein, muscle control, fat control, and the Fitness result.

Correlation analysis using Pearson's correlation coefficient found a statistically significant relationship between skeletal muscle mass and total body mass, in both the first measurement $(p<0.001)$ and the second measurement $(p<0.001)$. The correlation was positive: when one value increased, the other did as well (Table 2).

Correlation analysis done using Pearson's correlation coefficient revealed a statistically significant relationship between the level of adipose tissue and total body mass, in both the first measurement $(p<0.001)$ and the second measurement $(p<0.001)$. The correlation was positive: when one value increased, the other did as well (Table 3).

Correlation analysis done using the Pearson's correlation coefficient revealed a statistically significant relationship between body weight and height, and the basal metabolic rate, in both the first measurement $(p<0.001)$ and the second measurement $(p<0.001)$. The correlation was positive: when one value increased, the other did as well (Table 4).

Summing up, physical activity that lasted a month caused a statistically significant reduction in weight, adipose tissue, body mass index, percentage of body fat, waist-hip ratio, and visceral fat area and a statistically significant increase of skeletal muscle mass, body water, fat-free mass, basal metabolic rate, protein content, fat control, and total Fitness result.

\section{Discussion}

The dynamic development of science, technological advances, and the quick pace of our everyday life 
Table 1. Body composition analysis; a comparison of individual measurements

\begin{tabular}{|c|c|c|c|c|c|}
\hline \multirow[t]{2}{*}{ Variables } & \multicolumn{2}{|c|}{$1^{\text {st }}$ measurement } & \multicolumn{2}{|c|}{$2^{\text {nd }}$ measurement } & \multirow[t]{2}{*}{$P$-value } \\
\hline & Mean & SD & Mean & SD & \\
\hline Height [cm] & 166.9 & 7.73 & 166.9 & 7.78 & 0.877 \\
\hline Weight [kg] & 75.7 & 15.49 & 75.0 & 15.43 & $<0.001$ \\
\hline Skeletal muscle mass (SMM) [kg] & 27.3 & 5.49 & 27.5 & 5.55 & 0.020 \\
\hline Adipose tissue (FAT) [kg] & 26.4 & 9.02 & 25.3 & 8.93 & $<0.001$ \\
\hline Total body water (TBW) [l] & 36.1 & 6.64 & 36.3 & 6.74 & 0.029 \\
\hline Fat-free mass (FFM) [kg] & 49.4 & 9.08 & 49.7 & 9.20 & 0.024 \\
\hline Body mass index (BMI) & 27.1 & 4.53 & 26.8 & 4.57 & $<0.001$ \\
\hline Percentage of body fat (PBF) [\%] & 34.3 & 6.44 & 33.2 & 6.46 & $<0.001$ \\
\hline Waist-hip ratio (WHR) & 0.901 & 0.0472 & 0.898 & 0.0459 & 0.016 \\
\hline Visceral fat area (VFA) & 11.6 & 4.38 & 10.9 & 4.27 & $<0.001$ \\
\hline Basal metabolic rate (BMR) [kcal] & 1436.1 & 196.18 & 1442.6 & 198.60 & 0.024 \\
\hline Minerals [kg] & 3.5 & 0.63 & 3.5 & 0.63 & 0.142 \\
\hline Protein [kg] & 9.7 & 1.82 & 9.8 & 1.84 & 0.014 \\
\hline Muscle control [kg] & 0.8 & 1.51 & 0.8 & 1.64 & 0.931 \\
\hline Fat control $[\mathrm{kg}]$ & -12.4 & 8.51 & -11.3 & 8.31 & $<0.001$ \\
\hline Fitness result & 69.7 & 6.37 & 71.1 & 6.38 & $<0.001$ \\
\hline
\end{tabular}

SD - standard deviation, $p$ - significance level for a paired sample Student's t-test.

Table 2. The relationship between skeletal muscle mass and total body mass

\begin{tabular}{|c|c|c|c|}
\hline \multirow{5}{*}{ Weight $[\mathrm{kg}]$} & & & Skeletal muscle mass (SMM) \\
\hline & \multirow{2}{*}{$1^{\text {st }}$ measurement } & Pearson's correlation coefficient & 0.85 \\
\hline & & Significance (two-way) & $<0.001$ \\
\hline & \multirow{2}{*}{$2^{\text {nd }}$ measurement } & Pearson's correlation coefficient & 0.85 \\
\hline & & Significance (two-way) & 0.001 \\
\hline
\end{tabular}

Table 3. The value of Pearson's correlation coefficient. The relationship between the level of adipose tissue and total body mass

\begin{tabular}{|lccc|}
\hline \multirow{3}{*}{ Weight $[\mathrm{kg}]$} & \multirow{2}{*}{$1^{\text {st }}$ measurement } & Pearson's correlation coefficient & Adipose tissue (FAT) [kg] \\
\cline { 3 - 4 } & \multirow{2}{*}{$2^{\text {nd }}$ measurement } & Significance (two-way) & 0.86 \\
\cline { 3 - 4 } & & Pearson's correlation coefficient & $<0.001$ \\
\cline { 3 - 4 } & & Significance (two-way) & 0.85 \\
\hline
\end{tabular}

Table 4. The value of Pearson's correlation coefficient. The relationship between body weight and height, and the caloric needs

\begin{tabular}{|lcccc|}
\hline & & & Weight [kg] & Height [cm] \\
\cline { 3 - 4 } $\begin{array}{l}\text { Caloric } \\
\text { needs [kcal] }\end{array}$ & \multirow{2}{*}{$1^{\text {st }}$ measurement } & Pearson's correlation coefficient & 0.86 & 0.79 \\
\cline { 3 - 4 } & \multirow{2}{*}{$2^{\text {nd }}$ measurement } & Significance (two-way) & $<0.001$ & $<0.001$ \\
\cline { 3 - 5 } & & Pearson's correlation coefficient & 0.86 & 0.78 \\
\cline { 3 - 5 } & & Significance (two-way) & $<0.001$ & $<0.001$ \\
\hline
\end{tabular}


bring many benefits, but they can also have a negative effect on our health. Limited physical activity, living in a constant rush, and improper nutrition and misconduct pose a great threat to the development and structure of the human body and are the cause of the advance of civilisation diseases $[4,12]$. In a time of rapidly progressing problems of obesity and metabolic disorders, there is an ever greater problem with the occurrence of civilisation diseases. Body composition analysis is a very important element of diagnostic and therapeutic activities, but its main task is the prevention of the adverse effects of the above-mentioned problems in the present-day lifestyle. The fact that when all elements required to prepare the test are used the repeatability of the results is very high is an important element in favour of tests using BIA. The test's reliability rate is as high as $99 \%$. Body composition analysis has become a popular with the increase in the incidence of civilisation diseases, and thanks to the availability of devices that use this method. The test is done quickly, non-invasively, and without any danger to the participant [9, 10, 13-15]. At present, physical activity has become the manifestation of a lifestyle and a means to prevent civilisation diseases. People not only see physical activity as doing exercises to improve their condition, strength or health, but it also has a great impact on their system of values. It should be a part of everybody's life regardless of their age and social status. Keeping physically fit for many years has great consequences on the amount of adipose tissue, so that it is kept on a proper level, leading to an improved physical and mental condition, which results in improved fitness and improved social life in later years of life [16]. BMI is the basic gauge for assessing the body, allowing one to determine if a patient's weight is underweight, a normal value, or overweight. In the present paper, a normal value was found in $33.67 \%$ of the people, i.e. 33 participants. The research of Jakubiec and Jamrut [17] showed that group A had a mean of 24.2, meaning a normal value, and group B had 28.7, meaning overweight. Whereas the mean percentage of body fat in her research is close to the results obtained in the present paper. Jakubiec and Jamrut [17] showed a mean value of percentage of body fat of $33.6 \%$ in her group under study, which is a result lower by $0.7 \%$ from the one in this paper. This could be the result of the similarity of both groups under study when it comes to age. Both groups had people who were over 40 years old. The waist-hip ratio in the present paper amounted to 0.901, and in the study done by Jakubiec and Jamrut [17] it was classified at not much lower a level. The mean value of fatfree mass (FFM) was distinctly higher than in the research carried out by Jakubiec and Jamrut [17], which is most likely caused by the fact that, in the present paper, the participants were people who did regular physical exercises at a gym, which resulted in a greater muscle mass. In the research of Płaczkowska et al.
[18], who used the BIA method, it was observed that the median of BMI in a group of young people was within the normal range of body weight, whereas in the results of Stolińska and Wolańska [19], the value of BMI in the group of women on a traditional diet was an average of 30.1, so within the limits of class 1 obesity, and in the group of women on a vegetarian diet this was 24.3 , i.e. in the normal range. The average age of the people participating in the research of Stolińska and Wolańska [19] was comparable to that of the participants of the present paper. The percentage of body fat values in her research were closer to this paper's results for the group on a vegetarian diet, whereas the people on a traditional diet had that parameter distinctly higher, by as much as $5.9 \%$. The median of age in Płaczkowska's [18] work was 23.5, and the height in both studies was very similar. The median BMI in the present study was within the range that points to overweight, similarly to the research results obtained by Gacek [4]. The values of the body mass index and waist-hip ratio were lower in the same group. It was also found that there is a relationship between physical activity and some nutritional behaviours, by making more proper and rational choices of products and controlling the caloric values of food eaten. The mean value of total body weight was distinctly lower in the group of this paper, and it amounted to $75.7 \mathrm{~kg}$ on average. Height was classified at a similar level in both groups. Body weight in the present study was higher, whereas obesity was found in over $50 \%$ of the participants, which is a value similar to the research of Knyszyńska et al. [20]. The waisthip ratio in her group was at a higher level, which may be caused by a higher average age. The mean body weight differed in both studies and was around $8 \mathrm{~kg}$ more in the present study; the value of body height also differed, and was lower in the group of Knyszyńska et al. by $7.4 \mathrm{~cm}$ on average. The mean adipose tissue mass was at a similar level in both groups under study. The situation was similar with the fatfree mass content, which was found at a level of around $50 \mathrm{~kg}[4,15-20]$. The research conducted by Pietraszewska et al. [21] on a group of soldiers and police officers took up the issues of fat deposition and distribution in their bodies. The mean percentage value of adipose tissue in the police officers was lower by $2 \%$ than in the present paper. In the soldier's case, however, the mean was lower by $5.4 \%$. The body mass index was higher by 1 level, and that of the soldiers lower by 1.5 levels, than in the present study [21]. In subsequent research, Gacek [22] took up the subject of physical activity and nutrition in a group of doctors. The value of BMI in that group varied within the limits of overweight, whereas every tenth person was obese. The results of her research show that doctors dedicate time once a week for physical activity [22]. A group of students of various levels of physical activity, tested by Janiszewska [16] using bioelectrical im- 
pedance analysis, was divided into people physically passive and those who were active, and she found that passive students had a decidedly higher percentage of body fat and a higher BMI in comparison to the group who exercised actively. The values of height proved that their average was higher in the group of students. A similar percentage of body fat was found in the participants from this paper as that of the physically active students, whereas the muscle tissue value was much greater in the students. A positive value was also found in students who took up various forms of physical activity [16]. The results of the present research indicate that the percentage of adipose tissue, and the muscle tissue mass in a body were decidedly different from the results of Musiał and Lipert [23], who took up the subject of body composition analysis in adults who did long-distance running, and used the bioelectrical impedance analysis method. In the present study, adipose tissue amounted to an average of $34.3 \%$ and muscle tissue to $27.3 \mathrm{~kg}$, and in the study of Musiał and Lipert [23] these were $21.14 \%$ and $52.15 \mathrm{~kg}$, respectively. In the same research, the value of BMI was normal, whereas fat-free mass and adipose tissue mass were decidedly lower, than in the present research, which is undoubtedly the result of the amount of physical activity performed and the long period of training. Muscle tissue formed a greater part of the body in people who undertook long-distance running as a form of physical activity, than in those who trained at a gym and are part of the present research [23]. The study of body composition in young men, done by Całyniuk et al. [24], was based on the use of bioelectrical impedance analysis. Weight was found to be similar in the group of young men under study as in the present research, but the average height of the participants was far greater. The percentage of body fat amounted to around $12.9 \mathrm{~kg}$. The body mass index was slightly higher in the group under study in this paper. It was lower by 2.4 points than the group under study by Całyniuk et al. [24]. In the research undertaken by Sochacka and Wojtyłko [25], Płaczkowska et al. [18], and Gacek [26], physical activity that was undertaken additionally, had a positive influence on body parameters. The research presented in this paper clearly confirms that relationship. A statistically significant differentiation in body composition was found amongst the participants, depending on the undertaken physical activity [18, 25, 26]. Women over the age of 60 years took part in the research of Ogonowska-Słodownik et al. [27] on the subject of physical activity and body composition of people taking part in an organised physical activity. The mean value of height in the group under study was $160 \mathrm{~cm}$, i.e. $7 \mathrm{~cm}$ lower than the group under study in this paper. The mean body weight was not much lower, with an average of $68.1 \mathrm{~kg}$. The BMI was comparable in both groups under study. The average percentage of body fat in the present paper was lower.
In the research of Ogonowska-Słodowik et al. [27], BMI values were, on average, above normal, which at the age of the participants may show how greatly important regular physical activity is for functional performance, body composition, and quality of life. In both groups under study, satisfactory changes to body composition were found, testifying to the positive effect of physical activity [27].

\section{Conclusions}

The muscle mass gain is related to the total body mass gain, and our own research has shown a statistically significant relationship between these parameters. The reduction of body fat as a result of physical training reduces the overall body weight, and the difference between the amount of fat and the overall body weight is statistically significant. Height and weight have an impact on the body's caloric requirements. Analysis of the value of the basic metabolic index confirms that the higher the weight and height, the greater the daily caloric demand. Physical activity affects changes in body composition and the recorded values of body weight reduction, amount of fat, BMI, visceral fat level and skeletal muscle mass increase, and water and protein content are statistically significant.

\section{Conflict of interest}

The authors declare no conflict of interest.

\section{References}

1. Leszczyńska A. Sport to zdrowie! Refleksje o aktywności fizycznej Polaków. Acta Universitatis Lodzensis. Folia Sociologica 2013; 45: 179-189.

2. Zapała M, Kowalczyk B, Lubińska-Żądło B. Aktywność fizyczna a styl życia kobiet w wieku produkcyjnym. Medycyna Ogólna i Nauki o Zdrowiu 2015; 21: 391-397.

3. Wojtczak A. Zdrowie publiczne wyzwaniem dla systemów zdrowia XXI wieku. PZWL, Warszawa 2009.

4. Gacek M, Chrzanowska M. Rekreacyjna aktywność fizyczna a antropometryczne wskaźniki stanu odżywienia i zachowania żywieniowe pracujących fizycznie mężczyzn w wieku 20-60 lat z populacji wielkomiejskiej. Roczniki Państwowego Zakładu Higieny 2011; 62: 319-323.

5. Dżygadło B, Łepecka-Klusek C, Pilewski B. Wykorzystanie analizy impedancji bioelektrycznej w profilaktyce i leczeniu nadwagi i otyłości. Problemy Higieny i Epidemiologii 2012; 93: 274-280.

6. Wysocki J. Ocena składu ciała człowieka, dystrybucja tkanki tłuszczowej w organizmie. Medyczne Zeszyty Naukowe 2015; 2: 5-23.

7. Jakubiec D, Jarnut W, Jonak W, Chromik K, Sobiech KA. Skład ciała a jakość życia mierzona Kwestionariuszem Ogólnego Stanu Zdrowia D. Goldberga (GHQ12) u kobiet w wieku 55-60 lat. Przegl Menopauz 2012; 6: 478-481.

8. Ostrowska L, Stefańska E, Adamska E, Tałałaj E, Waszczeniuk M. Wpływ leczenia dietą redukcyjną na skład ciała i modyfikację składników odżywczych w dziennej racji pokarmowej u otyłych kobiet. Endokrynol Otył Zab Przem Mat 2010; 6: 179-188. 
9. Lewitt A, Mądro E, Krupienicz A. Podstawy teoretyczne i zastosowania analizy impedancji bioelektrycznej (BIA). Endokrynol Otył Zab Przem Mat 2007; 3: 79-84.

10. Kucharska K, Niemczyk S. Metody oceny ilości tkanki tłuszczowej u osób z przewlekłą chorobą nerek. Nefrol Dial Pol 2009; 13: 75-78.

11. https://inbodypoland.pl/?post_type=produkty\&p=453 2020.07.04

12. Lizak D, Budzowski A, Seń M, Czarny W. Przegląd antropometrycznych mierników otłuszczenia ciała stosowanych w diagnozowaniu otyłości. Hig Public Health 2016; 51: 124-133.

13. Socha M, Karmińska K, Chwałczyńska A. Porównanie zawartości tkanki tłuszczowej u młodych nieotyłych kobiet i mężczyzn oznaczonej metodą bioimpedancji (wersja bii tetrapolarna) i metodą fotooptyczną. Endokrynol Otył Zab Przem Mat 2010; 6: 18-25.

14. Drożdż D, Kwinta P, Pietrzyk JA, Drożdż M, Stancewicz-Pach K. Wskaźnik masy ciała (BMI) czy analiza bioimpedancji elektrycznej (BIA) - która metoda pozwala lepiej ocenić zawartość tkanki tłuszczowej u dzieci? Przegl Lek 2007; 64: 68-71.

15. Kwaśniewska M, Bielecki W, Kaczmarczyk-Chałas K, Pikala M, Drygas W. Ocena rozpowszechnienia zdrowego stylu życia wśród dorosłych mieszkańców województwa łódzkiego i lubelskiego - projekt WOBASZ. Przegl Lek 2007; 64: 61-64.

16. Janiszewska R. Ocena składu ciała metodą bioelektrycznej impedancji u studentów o różnym stopniu aktywności fizycznej. Med Og Nauki Zdr 2013; 19: 173-176.

17. Jakubiec D. Jamrut W. Skład ciała a jakość życia mierzona Kwestionariuszem Ogólnego Stanu Zdrowia Davida Goldberga (GHQ-12) u kobiet w wieku 55-60 lat. Przegl Menopauz 2012; 6: 478-481.

18. Płaczkowska S, Pawlik-Sobecka L, Kokot I, Żółcińska-Wilczyńska M, Piwowar A. Wykorzystanie bezpośrednich i pośrednich metod oceny profilu składu ciała u młodych osób - badanie pilotażowe. Fam Med Prim Care Rev 2015; 17: 33-38.

19. Stolinska H, Wolanska D. Analiza składu ciała kobiet na diecie tradycyjnej i wegetariańskiej. Żyw Człowieka Metabol 2015; 42: 13-22.

20. Knyszyńska A, Bażydło M, Zabielska P, Karakiewicz B, Lubkowska A. Skład ciała i zaburzenia depresyjne u osób z zespołem metabolicznym po 55. roku życia. Fam Med Prim Care Rev 2016; 18: 128-131.

21. Pietraszewska J, Burdukiewicz A, Andrzejewska J, Stachoń A. Poziom i dystrybucja otłuszczenia oraz postawa ciała zawodowych żołnierzy i policjantów. Probl Hig Epidemiol 2012; 93: 759-765.

22. Gacek M. Zachowania żywieniowe i aktywność fizyczna w grupie lekarzy. Probl Hig Epidemiol 2011; 92: 254-259.

23. Musiał KA, Lipert A. Analiza składu ciała dorosłych osób amatorsko trenujących biegi długodystansowe. Med Sport 2017; 33: 139-146.

24. Całyniuk Z, Sadek A, Złoteńka-Synowiec M, Malczyk A Analiza składu ciała młodych mężczyzn. Młodzi Naukowcy 2018; I: 20-26.

25. Sochocka L, Wojtyłko A. Aktywność fizyczna studentów studiów stacjonarnych kierunków medycznych i niemedycznych. Environm Med 2013; 16: 53-58.

26. Gacek M. Wybrane aspekty stylu życia pracowników branży hotelarskiej. Rocz Panstw Zakł Hig 2012; 63: 233-238.
27. Ogonowska-Słodownik A, Kosmol A, Morgulec-Adamowicz N. Aktywność fizyczna, skład ciała i sprawność funkcjonalna kobiet powyżej 60 roku życia uczestniczących w zorganizowanej aktywności fizycznej. Gerontol Pol 2016; 24: 102-108.

\section{Address for correspondence:}

\section{Prof. Zbigniew Śliwiński}

Collegium Medicum

Institute of Health Sciences

Kielce, Poland

Phone: +48600 077794

E-mail: zsliwinski@ujk.edu.pl, jakub.jedlikowski@wp.pl 